DOI https://doi.org/10.30525/978-9934-26-005-6-14

\title{
ПІДВИЩЕННЯ РІВНЯ КОМПЕТЕНТНОСТІ ПОСАДОВИХ ОСІБ ОРГАНІВ МІСЦЕВОГО САМОВРЯДУВАННЯ
}

\author{
Мірко Н. В. \\ кандидат наук з державного управління, \\ дочент кафедри публічного управління та адміністрування \\ Київського національного \\ торговельно-економічного університету \\ м. Київ, Украӥна
}

На сьогоднішній день всі місцеві органи влади є важливим елементом політичної системи України у механізмі народовладдя. Організація публічної влади на місцях здійснюється або через місцеві органи державної виконавчої влади, які призначаються центральними органами виконавчої влади, або через місцеві органи, які обираються населенням, що проживає на певній території та має закріплений статус відповідної адміністративно-територіальної одиниці. Найважливішою функцією цих органів $\epsilon$ місцеве державне управління. Взагалі місцеве самоврядування можна розглядати як організацію публічної влади на місцях, 3 відповідною діяльністю місцевих органів та їх посадових осіб. В наш час місцеве самоврядування являє собою один з основних інститутів громадянського суспільства, від якого повною мірою залежить вдале функціонування територіальних громад нашої країни. Отже, саме від компетенцій органів місцевого самоврядування та від уміння якісно та кваліфіковано застосовувати свої повноваження, залежить якість та рівень життя населення.

Процес розбудови системи місцевого самоврядування, започаткованої на принципах Свропейської хартії місцевого самоврядування, $\epsilon$ одним із стратегічних завдань розвитку України як демократичної держави. Практика свідчить, що особливо нагальним $є$ пошук та ствердження засадничих основ 
існування держави, функціонування публічно-управлінських інститутів, формування простору діалогу та довірою між владою та громадянами. Виявлення ціннісних підвалин публічного управління, що надає осмисленості та змістовної наповненості публічно-управлінським відносинам.

В зв'язку 3 переходом на нову модель публічного управління в зарубіжній та вітчизняній літературі активізуються дослідження 3 теоретичного обгрунтування проблеми нового публічного менеджменту як інноваційного підходу до надання послуг населенню. У світі існують різні точки зору, які розкривають якісно нові підходи до розуміння компетентності. Актуальним для дослідження $€$ визначення поняття компетентності як готовності на професійному рівні виконувати свої посадові і фахові обов'язки відповідно до сучасних теоретичних надбань і кращого досвіду, наближення їх якості до світових вимог і стандартів [1].

Узагальнюючи визначення науковців, можна стверджувати, що компетентність - це певний рівень інтегрування знань, умінь, навичок, досвіду та особистих якостей фахівця, який забезпечує ефективність та якість виконуваної ним професійної діяльності.

Особливої значущості в суспільстві, зокрема набуває професійна компетентність службовця, що диктується вимогами життя i висувається на передній план. Професійна компетентність - здатність особи в межах визначених за посадою повноважень застосовувати спеціальні знання, уміння та навички, виявляти відповідні моральні та ділові якості для належного виконання встановленних завдань та обов'язків, навчання, професійного та особистісного розвитку. 3 позиції New Public Management по-новому розглядаються підходи до виконання чиновниками публічних функцій, ключовими 3 яких $€$ підвищення відповідальності за надання послуг населенню, підвищення якості послуг що надаються.

Поняття «компетенція» стосовно до органів місцевого самоврядування включає в себе не лише повноваження. Повноваження - це відповідні права і обов'язки, а компетенція включає в себе окрім повноважень, ще й предмети відання. Відання повинно визначати ті сфери життя, в яких задіяні 68 
конкретні органи місцевого самоврядування. Тому компетенції органу місцевого самоврядування представляють собою визначення тієї сфери місцевого життя, в якій діє даний орган місцевої влади. Отже, компетенція органів місцевого самоврядування - це визначені Конституцією та чинним законодавством держави предмети відання, права та обов'язки суб'єктів системи місцевого самоврядування, необхідні для реалізації завдань і функцій місцевого самоврядування на відповідній території [2].

Повноваження органів місцевого самоврядування діляться на власні і делеговані. «Законодавець наділяє органи місцевого самоврядування владними повноваженнями 3 метою реалізації ними публічних завдань, які становлять категорію власних завдань. Проте в процесі здійснення публічної діяльності може виникати необхідність передачі виконання інших завдань, ніж ті, які визначені в базових законах про місцеве самоврядування. Ці завдання є делегованими. Власні виконуються самостійно, а під час виконання делегованих відбувається контроль 3 боку суб'єкта, який здійснив делегування» [3].

Основні аспекти служби в органах місцевого самоврядування вперше визначені в Указі Президента України «Про заходи щодо впровадження Концепції адміністративної реформи в Україні: «Реформування державної служби в Україні покликано забезпечити підбір і розстановку високопрофесійних, чесних і патріотично налаштованих кадрів апарату управління. Запровадження інституту служби в органах місцевого самоврядування має базуватися на таких концептуальних положеннях: служба в органах місцевого самоврядування $\epsilon$ автономною формою публічної служби і являє собою професійну, на постійній основі діяльність громадян України, які займають посади в органах місцевого самоврядування, що спрямована на реалізацію територіальною громадою свого права на місцеве самоврядування та окремих повноважень органів виконавчої влади, наданих законом; служба в органах місцевого самоврядування базується на загальних принципах публічної служби в Україні і здійснюється на основі єдиної державної політики. Крім того, в і1і основу мають бути покладені 
специфічні принципи, притаманні лише цій формі публічної служби: самостійності органів та посадових осіб місцевого самоврядування в межах їх повноважень; відповідальності службовцями перед територіальною громадою; поєднання загальних вимог до служби в органах місцевого самоврядування, встановлених законодавством, національних, історичних та місцевих традицій служби, визначених статусами територіальних громад» [4].

Посадовою особою місцевого самоврядування є особа, яка працює в органах місцевого самоврядування, має відповідні посадові повноваження щодо здійснення організаційнорозпорядчих та консультативно-дорадчих функцій i отримує заробітну плату за рахунок місцевого бюджету [3].

Національне агентство України з питань державної служби затвердило «Загальні правила етичної поведінки державних службовців та посадових осіб місцевого самоврядування» в яких зазначено, що основною метою діяльності державних службовців та посадових осіб місцевого самоврядування $\epsilon$ служіння народу України та територіальній громаді, охорона та сприяння реалізації прав, свобод і законних інтересів людини і громадянина. Ці Правила регулюють етичні засади діяльності державних службовців та полягають у дотриманні принципів етики державної служби. Під час прийняття на службу в місцевих органах влади особа ознайомлюється 3 цими Правилами, та зобов'язується дотримуватися їх у своїй подальшій службовій діяльності. Етика державного службовця це система придатних та усвідомлених норм поведінки, певний порядок дій, правил взаємин і принципів державно-службових відносин, що належать даному суспільству i $\epsilon$ нормами загальнолюдської моралі. Професіоналізм і ефективність роботи державного службовця - це показник його моральності, вірності своєму професійному обов'язку [5].

Влучно, на нашу думку, з цього приводу висловився Говард Віттон (спеціаліст-консультант i практик у сфері етики державної служби, антикорупційної політики та нарощування потенціалу державної служби колишній Головний адміністратор Групи з етики програми OECP SIGMA), який сказав: «Якщо ми 70 
не навчатимемо професійної етики державних службовців, і не управлятимемо нею відповідним чином, ніякий кодекс чи процедура не будуть ефективними, оскільки вони не будуть зрозумілими. А якщо ми будемо це робити, кодекси та більшість процедур будуть непотрібні» [6].

При цьому у етизації діяльності ми вбачаємо головним не стандартизацію й не надмірне підпорядкування поведінки чиновника жорстким правилам, а глибинне усвідомлення змісту цих правил та самодисципліну по їх дотриманню, що має вплинути на гуманізацію стосунків 3 іншими суб'єктами. Справжня етика службових відносин означає не формальне дотримання моральних норм, а прояв у повсякденній діяльності справжньої людяності, поваги до інших, шанування прав людини i громадянина. Етична проблематика глибоко укорінена в контексті ціннісних вимірів публічного управління. Етика акцентує увагу на цінностях, що мають бути наявними в публічно-управлінських рішеннях, дає моральне обгрунтування як напрямкам політики так $\mathrm{i}$ конкретним публічноуправлінським рішенням; допомагає розв'язати ціннісні конфлікти, що спроможні загальмувати здійснення політики, $\epsilon$ системо утворюючим чинником для функціонування владних структур та поводження представників публічного управління.

На сьогодні в Україні етика і висока кваліфікація державного службовця є засадничими умовами успіху реформ, що запроваджуються в державі i саме вони складають гуманістичну основу організації професійної діяльності посадових осіб. Отже, важливим завданням публічного управління $є$ підвищення рівня морально-етичних основ публічного службовця, озброєння його знаннями, завдяки яким можуть бути більш ефективно подолані протиріччя у його професійній діяльності. Також потребують подальшого дослідження та вирішення питання відповідальності публічного службовця за порушення правил етики, які будуть не тільки зафіксовані в нормативних документах, а й найдуть обов'язкового виконання на практиці. 


\section{Література:}

1. Компетенція і компетентність: досвід теорії, теорія досвіду М.С. Головань.URL. ttps://essuir.sumdu.edu.ua/bitstream/ 123456789/52560/5/Holovan_competence.pdf (дата звернення 21.10.2020).

2. Конституція України URL: https://zakon.rada.gov.ua/laws/ show/254к/96-вр від 28.06.1996 р.

3. Закон України «Про місцеве самоврядування в Україні» URL: https://zakon.rada.gov.ua/laws/show/280/97-вp від 21.05.1997 р. в редакції від 11.01.2019 р.

4. Указ Президента України «Про заходи щодо впровадження Концепції адміністративної реформи в Україні. URL: https://zakon.rada.gov.ua/laws/show/810/98 (дата звернення 23.10.2020).

5. Василевська Т.Е., Саламатов В.О., Марушевський Г.Б. Етика державного управління : підручник / Т. Е. Василевська, В.О. Саламатов, Г.Б. Марушевський ; за заг. ред. Т.Е. Василевської. - К. : НАДУ, 2015. - 204 с.

6. Горб В. Г. Основна освітня програма закладу вищої освіти: проблеми і рішення / В. Г. Горб // Стандарти і моніторинг в освіті. - 2004. - № 2 - С. 22. 